\title{
BACTERIOLOGICAL STUDIES OF CLOSTRIDIUM PERFRINGENS IN FISH
}

\author{
${ }^{1}$ Lamyaa M. Reda and ${ }^{2}$ H. Mona \\ ${ }^{1}$ Central Lab., Vet. Hospital, Faculty of Vet. Med., Zagazig Univ., Egypt \\ ${ }^{2}$ Animal Health Research Institute, Zagazig, Egypt
}

\begin{abstract}
The current research was carried out on one hundred and thirteen random fish samples (56 processed and 57 unprocessed) collected from different localities in El-Sharkia Governorate, Egypt to obtain a complete picture of $C$. perfringens. Bacteriological and biochemical examination was done on the isolates. Nagler's test was applied on the recovered. $C$. perfringens isolates. The total incidence of positive samples from 56 processed fish samples were 32 isolates (57.1\%) and from 57 unprocessed fish samples were 34 isolates (59.6\%). The. Typing of $C$. perfringens isolates revealed that the incidence of toxigenic and non-toxigenic isolates were 84.8 and $15.2 \%$ respectively. Typing of toxigenic strains of $C$. perfringens revealed that $C$. perfringens type $A$ was the most predominant one comparing with type D. Immune diffusion test showed that 17 and 11 toxins of types $A$ and $D$ gave identified reaction with incidences of 47.2 and $55 \%$ respectively.
\end{abstract}

\section{INTRODUCTION}

Fish are considered one of the most widely accepted and valuable food in most countries. Egypt is currently one of the fastest growing countries in the field of aquaculture to solve protein shortage problem.This increase in aquaculture has led to the further spread of diseases (Bahnasawy, 2009 and Rajinikanth et al., 2010) The presence 
of microbial pathogens, especially those of bacterial origin is one of the most significant factors affecting fish culture (Post,1983). Anaerobic bacteria are important groups of microorganisms which are responsible for reduction of growth rate, increased mortality and high costs of treatment with antibiotics in addition to many public health hazards (Samaha et al .,2004 and Damir et al., 2005).

C. perfringens is widely distributed in soil and intestinal contents of man and animals. It has a great effect on the human health causing food poisoning. It also causes a number of human diseases ranging from necrotic enteritis to wound infection and gas gangrene. This pathogenicity is associated with lethal extra cellular toxins which have been defined as enzyme activity as collagenase, hyaluronidase and deoxyribonuclease (Bradley et al., 2013). The colonies of C. perfringens are smooth, round, glistening and surrounded by double revise zone of hemolysis (Quinn et al.,1994) C. perfringens are large Gram-positive rods (0.6-2.4 x 1.3-9.0 $\mu \mathrm{m})$, encapsulated, non-motile, spore forming, fermentative and catalase negative (Cato et al., 1986). The spores of some Clostridia species are high heat resistant and may survive heat treatment of canned foods. If the surviving spores germinate and the vegetative cells grow, spoilage will occur (Banwart, 1989). C. perfringens is divided into 5 types (A, B, C, D and E) on the basis of the production of 4 major toxins $(\alpha, \beta, \varepsilon$ and $\iota)$ each type had been linked to specific diseases (Petit et al., 1999). hence, the main goals of the present study were: Identification and typing of $C$. perfringens isolates from processed and unprocessed fish samples. Serological identification of $C$. perfringens toxins by toxin-antitoxin neutralization test, minimal lethal dose in mice and immune diffusion test. 


\section{MATERIAL AND METHODS}

\section{Samples:}

A total of 113 fish samples were collected from large supermarket and retail fish shops in El-Sharkia Governorate. The samples were 56 processed fish samples \{canned salmon, canned mackerel, salted sardine, renga(Smoked Herring) and feisekh(Salted Mugil cephalus) $\}$ and 57 unprocessed fish samples \{Nile cat fish(Karmout), Tilapia nilotica (Bolti), danis(Gilt-head seabream), fresh water sardine, rossi (Atlantic Mackerel), macaroni (Brushtooth Lizard fish) and bagha (Leer fish) \}.

\section{Bacteriological Examination:}

\section{Isolation and Identification of $C$. perfringens:}

The surface of each sample was sterilized and bean size pieces were obtained from the deeper parts of each sample and inoculated separately into tubes of freshly prepared cooked meat broth medium. All tubes were incubated anaerobically in the anaerobic jar using anaerobic gas generating kits (Oxoid) at $37^{\circ} \mathrm{C}$ for 48 hours. For isolation of $C$. perfringens, a loopful from the previously incubated tube was streaked onto the surface of $10 \%$ sheep blood agar with neomycin sulphate (200 $\mu \mathrm{g} / \mathrm{ml}$ ) and incubated for 24 hours at $37^{\circ} \mathrm{C}$ in the anaerobic jar. The suspected colonies of $C$. perfringens were picked up and examined for their morphological and culture characters (Vaikosen and Muller, 2001), microscopical examination of stained films from the suspected colonies with Gram's stain and biochemical tests were done (Koneman et al., 1992).

Nagler's test by half antitoxin plate was done as previously described (Smith and Holdman 1968). The attack of alpha toxin that is produced by all types of $C$. perfringens, on lecithin is inhibited by alpha 
antitoxin (Jokily et al., 1980). Typing of C. perfringens toxins by dermonecrotic test Preparation of toxins and Diagnostic $C$. perfringens antitoxin type A,B,C,D, and E (Burroguns, Welcome, Bechenham, London, England) (Gadalla et al.,1974) and the application of the dermonecrotic test (Oakley and Warrack 1953 and Quinn et al., 2002) were carried out. Serological identification of $C$. perfringens toxin was done as previously described (Smith and Holdman 1968).

Determination of minimum lethal doses (MLD) of the prepared C.Perfringens toxins:

The test was done using the prepared toxins (alpha toxin of type A and epilson toxin of type D) as described previously (Eman, 1996).

\section{Immune diffusion test:}

Agar gel immune diffusion test was used to determine the relationship between antigen and antibodies (Mary, 1990).

\section{RESULTS AND DISCUSSION}

Clostridium perfringens is more widely spread than other pathogenic bacteria; its principle habitats are in the soil and the intestinal content of the man and animals(Elham and Abou El-Roos,2011). There is much evidence that obligate anaerobic organisms are probably the principal sources of infection in human beings, domestic animals and fish (Bradley et al., 2013). In recent decades, many surveys have been conducted on the incidence of $C$. perfringens in raw and processed meat and poultry. This report indicates wide spread occurrence of this organism in processed and unprocessed fish (Elham and Abou El-Roos, 2011). 
Bacteriological Studies Of Clostridium Perfringens In Fish.

\section{Incidence of $C$. perfringens Isolates in Processed Fish Samples:}

Table 1 shows that the prevalence of $C$. perfringens in 56 processed fish samples was $57.1 \%$. The isolation of positivity was seen in feisekh, renga and salted sardine by percentages of $82.3 \%, 80.0 \%$ and $75 \%$, respectively, but there was no $C$. Perfringens isolates from canned products such as mackerel and salmon.

Table (1): Incidence of C.perfringens in different types of processed fish samples

\begin{tabular}{||l||c||}
\hline \multicolumn{1}{|c|}{ Processed fish samples } & No. of + ve samples/Total number \\
\hline \hline Canned salamon & $0 / 11(0 \%)$ \\
\hline Canned mackerel & $0 / 5(0 \%)$ \\
\hline Salted sardine & $6 / 8(75 \%)$ \\
\hline Renga & $12 / 15(80 \%)$ \\
\hline Feisekh & $14 / 17(82.3 \%)$ \\
\hline \hline Total & $\mathbf{3 2 / 5 6 ( 5 7 . 1 \% )}$ \\
\hline
\end{tabular}

Table (2): Incidence of C.perfringens in different types of unprocessed fish samples

\begin{tabular}{||l||c|}
\hline \multicolumn{1}{|c|}{ Un-processed fish samples } & No. of +ve samples/total Number \\
\hline \hline Nile cat fish & $8 / 10(80.0 \%)$ \\
\hline Tilapia nilotica & $5 / 8(62.5 \%)$ \\
\hline Danis & $4 / 8(50.0 \%)$ \\
\hline Sardine & $3 / 8(37.5 \%)$ \\
\hline Rossi & $5 / 8(62.5 \%)$ \\
\hline Macaroni & $5 / 8(62.5 \%)$ \\
\hline Bagha & $4 / 7(57.1 \%)$ \\
\hline \hline Total & $\mathbf{3 4 / 5 7 ( 5 9 . 6 \% )}$ \\
\hline
\end{tabular}

Table (3): Typing of C.perfringens isolates recovered from fish samples

\begin{tabular}{|c|c|c|c|c|}
\hline \multirow{2}{*}{$\begin{array}{l}\text { Type of fish } \\
\text { samples }\end{array}$} & \multirow{2}{*}{$\begin{array}{c}\text { Non toxigenic C.perfringens/ } \\
\text { total isolates }\end{array}$} & \multicolumn{3}{|c|}{ Toxigenic $C$. perfringens isolates } \\
\hline & & $\begin{array}{l}\text { C.perfringens } \\
\text { type A }\end{array}$ & $\begin{array}{l}\text { C.perfringens } \\
\text { type D }\end{array}$ & Total \\
\hline Processed & $5 / 32(15.6 \%)$ & $17 / 32(53.1 \%)$ & $10 / 32(31.3 \%)$ & $27 / 32(84.4 \%)$ \\
\hline Unprocessed & $5 / 34(14.7 \%)$ & $19 / 34(55.9 \%)$ & $10 / 34(29.4 \%)$ & $29 / 34(85.3 \%)$ \\
\hline Total & $10 / 66(15.2 \%)$ & $36 / 66(54.5 \%)$ & $20 / 66(30.3 \%)$ & $56 / 66(84.8 \%)$ \\
\hline
\end{tabular}

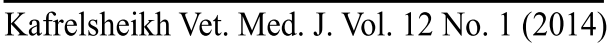


These results coincide with those recorded by (Kassem, 1996) who stated that Clostridium spp. could be isolated from the three types of examined salted fish (feisekh, molouha and salted sardines), while canned product is safe and free from anaerobic microorganisms. The present study results also go hand in hand with those recorded by (Richardson, 1972).

\section{Incidence of $C$. perfringens Isolates in Unprocessed Fish Samples:}

Table 2 shows that out of 57 unprocessed fish samples, 34 (59.6\%) were positive for $C$. perfringens. The highest incidence of positivity was shown in Nile cat fish by a percentage of $80.0 \%$, while the lowest incidence of positivity appeared in sardine with an incidence of $37.5 \%$.

These results go hand in hand with those obtained by Schocken (1996), Peterson et al., (2002) and Marzouk et al., (2005) who mentioned that $C$.perfringens need presence of high amount of organic pollutions of human and animal origin and strict anaerobic condition to grow and become pathogenic. They also added that the high incidence of $C$. perfringens is due to the heavy use of poultry dropping and animal manure that usually contain $C$. perfringens. On the other hand, Enany et al., (1989) reported that Nile cat fish possess highest prevalence with $C$. perfringens as Nile cat fish are highly exposed to subclinical infection with different levels of $C$. perfringens toxin so that they become immunized without showing symptoms of illness.

\section{Identification of $C$. perfringens Isolates:}

The suspected colonies of $C$. perfringens were Gram-positive, short plumb, rarely sporulated and non-motile bacilli when they were stained with Gram's stained. It was apparent that sheep blood agar with neomycin sulphate $(200 \mu \mathrm{g} / \mathrm{ml})$ is a perfect medium for isolation of $C$. perfringens rather than other Clostridium species and gave double zones 
of hemolysis. All the recovered strains in this work were fermentative to different sugars as glucose, maltose, lactose, sucrose and mannose with production of acid and gases, gelatin liquefiers, litmus milk positive, catalase, oxidase and indole negative. Similar results were recorded by several authors as (Vaikosen and Muller (2001) and Assis et al., (2002).

\section{Results of Nagler's Test for Identification of $C$. perfringens Isolates:}

The obtained results revealed that 10 out of 66 isolates were toxin producer on egg yolk agar medium. These results go hand in hand with those recorded by Smith and Holdman, (1968) who applied Nagler's test using half antitoxin plate to detect lecithinase activity of alpha toxin of different types of $C$. perfringens.

\section{Typing of $C$. perfringens Isolates by Intradermal Injection of Guinea} Pigs:

The typing of $C$. perfringens by intradermal injection of guinea pig revealed that the incidence of toxigenic and non-toxigenic isolates were 84.8 and $15.2 \%$, respectively as shown in table (3). The action of $C$. perfringens type "A" (alpha toxin) appeared as an irregular area of yellowish green necrosis tented to spread downward, while that of type "D" (epilson toxin) appeared as a circular whitish green necrosis with few small areas of purplish hemorrhagic necrosis Stern and Batty, (1975).

Typing of the toxigenic $C$. perfringens isolates revealed that C.perfringens types $\mathrm{A}$ and $\mathrm{D}$ were the most predominant ones with percentages of $54.5 \%$ and $30.3 \%$, respectively. Such finding is similar to that of, Enany et al., (1989), Aschfalk and Muller, (2002) and Songer and Dale, (2005) who recorded presence of $C$. perfringens types A and D with percentage of 50 and 25 respectively in Nile tilapia samples. 


\section{Toxin Antitoxin Neutralization Test:}

All sixty six $C$. perfringens isolates were identified by toxin antitoxin neutralization tests. The results showed the protection of the injected albino guinea pigs because of neutralization of each toxin with its specific antitoxin. Also, the obtained results revealed that $C$. perfringens type $\mathrm{A}$ was the most predominant one among the total recovered isolates as shown in table (3). These results are in accordance with Stark and Duncan, (1972) and Jokily et al., (1980) who deserved that alpha toxin is the most important toxin produced by all types of $C$. perfringens.

\section{Results of MLD Test in Mice:}

All sixty six $C$. perfringens isolates were tested for MLD in mice and the obtained results showed that the minimum lethal doses for $C$. perfringens types A and D were 1/16 and 1/8, respectively. Aloisi, (1988) found that the minimum lethal dose for C. perfringens is $0.014 \mathrm{MLD} / \mathrm{ml}$.

\section{Results of Immune Diffusion Test:}

Immune diffusion test revealed that out of 36 C. perfringens type A toxin, 17, 7 and 12 toxin showed identity, non-identity and partial identity with percentages of $47.2 \%, 19.4 \%$ and $33.3 \%$, respectively. Furthermore, out of 20 of $C$. perfringens type D toxin, 11, 3 and 6 showed identity, non-identity and partial identity with percentages of $55.0 \%, 15 \%$ and $30.0 \%$, respectively. These results go hand in hand with those recorded by Aloisi, (1988) and Mona, (2009) who reported that $C$. perfringens type A toxin showed identity, non identity and partial identity with percentage of $46.2 \%, 18.3 \%$ and $36.5 \%$, respectively. Furthermore $C$. perfringens type D toxin showed identity, non-identity and partial identity with percentages of $53.2 \%, 17 \%$ and $29.8 \%$, respectively. 
In conclusion, in the present study the highest incidence of C.perfringens isolates was in feisekh and Nile catfish, while the lowest incidence was in canned salamon and mackerel in El-Sharkia Governorate . Moreover , the obtained data may be important for understanding C.perfringens epidemiology and a control strategy plan. Further research is needed to study C.perfringens gene from fish strains to trace the source of infection.

\section{REFERENCES}

- Aloisi, R.M.(1988): Principles of immunology and immunodiagnostics. Philadelphia, Lea and Febiger.

- Aschfalk, A. and Muller W. (2002): C. Perfringens toxin types from wild caught Atlantic cod (Gadus morhual.), determined by P.C.R and ELISA. Can. J. Microbiol., 48(4): 365-368.

- Assis, R.A., Uzal F.A., Santana F.J., Dias L.D. and Parreirasa P.M. (2002): Isolation of C.perfringens type D from a suckling calf with ulcerative abomasitis. Arch. Med. Vet., 2: 287-292.

- Bahnasawy, M. (2009): Effect of dietary protein levels on growth performance and body composition of Monosex Niletilapia, Oreochromis niloticus L. reared in fertilized tanks. Pakistan Journal of Nutrition, 5: 674-678.

- Banwart, G.J.(1989): Basic Food Microbiology, $2^{\text {nd }}$ ed. VannoStrand, Reinhold New York.

- Bradley G.,Gillian B., Holger B. and Michel R.(2013):Clostridium perfringens Epilson toxin:A malevolent molecule for animals and man.Toxins (basel) 5 (11):2138-2160. 
- Cato, E.P., George W.L. and Finegold S.M. (1986): Genus Clostridium. In: Bergey's Manual of Systematic Bacteriology. Vol.2. Edited by Sneath, P.H.A., N.S. Mair, M.E. Sharpe and J.G. Hott. Williams and Willins Co., Baltimore, pp: 1141-1200.

- Damir, K., Bozirar K. and Emin T.(2005): Differences in bacterial population in rainbow trout (oncorhynchus my kiss walbum) fry after transfere from incubator to pools. Food Technol. Biotechnol., 4: 189193.

- Elham,I.Atwa and Abou El-Roos N.A.(2011): Incidence of Clostridium perfringens in meat products at some Egyptian Governorates. International Journal of Microbiological Research, 3: 196-203.

- Eman, M.N. (1996): Studies on rapid methods for diagnosis of pulpy kidney and lamb dysentery, Ph. D. thesis (Microbiology), Fac. Vet. Med., Cairo University.

- Enany, M., El-bouhy Zeinab M., Saleh G., and El-Kenawy A. (1989): Preliminary tudies on Clostridial infection in some fresh water fish. Bull. Fac. Sci. Zagazig Univ., 11: 9-25.

- Gadalla, M., Farrag I. and Sharaf D. (1974): Effect of growth requirement on the improvement of clostridial vaccines. J. Egypt Vet.Med. Ass., 2: 19-28.

- Jokily, W.K., Willet H.P. and Amos D.B. (1980): Zinsser Microbiology. $17^{\text {th }}$ Ed. Appleton Century Crofts, New York.

- Kassem, G.M. (1996): Health hazard due to marketed salted fishes.M.V.Sc., Thesis, Fact. Vet. Med.,Cairo Univ.

- Koneman E.W., Allen S.D., Dowell V.R. and Summers H.W. (1992): Colour Atlas and Textbook of Diagnostic Microbiology. $4^{\text {th }}$ Ed. J.B. Lippin Cott, New York, London. 
- Mary, L. (1990): Immunology and Serology in Laboratory Medicine. Seventh Edition. Butter Wroth-Heinemann Ltd.

- Marzouk, M.S.M., Ali M.M., Basma S.M., Mahmoud A.M. and Abdel-Salam M.I.(2005): A contribution on anaerobic bacterial infection in culturedfresh water fish. J.Egypt. Vet. Med. Assoc., 65(3): 123-140.

- Mona, H. (2009): Incidence of C. Perferingens alpha-toxin in processed and unprocessed fishes. Thesis, M.V.Sc., Faculty of Veterinary Medicine, Zagazig Univ.

- Oakley, C.L. and Warrack G.H. (1953): Routine typing of C. Wechii. J.Hyg.Gamb., 51: 102-107.

- Peterson, A., Andersen T.S., Kaewmak T., Somsiri T. and Dalsgard A. (2002): Impact of intergrated fish farming on antimicrobial resistance in a pond environment. App. Environ. Microbiol., 12: 6063-6042.

- Petit, L., Gibert M. and Popoff M. (1999):C. perfringens toxinotype and genotype. Trends Microbiol., 7: 104-110.

- Post, G.W.(1983): Textbook of Fish Health. $2^{\text {nd }}$. T.F.H. pupl. Inc. Lt., pp: 34-44.

- Quinn, P.J., Markey B.K., Carter M.E., Donnelly W.J., Leonard F.C.and Maguire D.(1994): Clostridium species. In: Clinical Veterinary Microbiology. $2^{\text {nd }}$ Eds Wolfe Publishing. London, pp: 191-208.

- Quinn, P.J., Markey B.K., Carter M.E., Donnelly W.J., Leonard F.C. and Meguire D. (2002): Veterinary microbiology and microbial disease. $2^{\text {nd }}$ Ed., Blackwell Science, pp: 84-96.

- Rajinikanth, T., Ramasamy R. and Ravi V. (2010): Efficacy of Probiotics, growth promotors and disinfectants in shrimp grow out farm. Am. Euras. J. Agric. Eviron. Sci., 3: 347-354. 
- Richardson, K.C.(1972): Microbial Spoilage in Australian Canned Foods.1955-1968. Food Technol. Austral., 24: 106-107.

- Samaha, H.A., Hagga Y. and Nadia M. (2004): Brackish and Marine Water fish as a source of certain bacterial pathogens to human beings. In the Proceedings of the $4^{\text {th }}$ Sci. Conference for Vet. Med. Researches, Fac. Vet. Med., Alex. Univ., 2-4 October.

- Schocken, P., Sampaio A.A.M. and Berchielli S.C.P.(1996): Microbiological analyses of poultry litter used for ruminant feeding. A quivo Brasilerio de Medinino Vet. E. Zootennia, 4: 435-443.

- Smith, L.D. and Holdman S.(1968):The pathogenic anaerobic

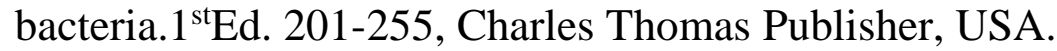

- Songer, J.G. and Dale W.M. (2005): Clostridial abomasitis in calves: case report and review of the literature. Anaerobe. 11: 290-294.

- Stark, R.L. and Duncan C.L. (1972): Purification and biochemical properties of C.perfringens type A enterotoxin. Infection and Immunity, 6(5): 662-673.

- Stern, M. and Batty I.(1975): Pathogenic Clostridia. Butterworth, London, Boston.

- Vaikosen, E. and Muller W.(2001): Evaluating biochemical tests for isolation and identification of C. perfringens in faecal Samples of Small Ruminants in Nigeria. Bulletin of Animal Health and Production in Africa, 49: 244-248. 


$$
\begin{aligned}
& \text { در اسة بكتريولوجيه للكلوستريديم بيرفرجينز فى الأسماك } \\
& \text { لمياء محمد رضا" ، منى محمد حمدى" } \\
& \text { " المعمل المركزى- مستثفى الطب البيطرى - جامعة الزقازيق } \\
& \text { " قسم البكتريولوجيا - معهة بحوث صحة الحيوان بالزقازيق }
\end{aligned}
$$

تعتبر الأسماك واحدة من أهم مصادر اللحوم الغنية بالبروتين والمفيدة للاستهلاك الآدمي وبالتالي فإن دراسة الأعراض والمتغيرات التي تظهر على الأسماك والتني تسببها البكتريا وبالأخص الكلوستريديم بيرفرنجينز تساعد فى الحماية من الأمراض. أجريت هذه الدراسة على 113 عينة عشوائية من الأسماك المصنعة والغير مصنعة جُمعت من أماكن مختلفة من أسواق مدينة الزقازيق (56 عينة من الأسماك المصنعة و 57 عينة من الأسماك الغير مصنعة). اثبت الفحص البكتريولوجى ان هناك 32 عينة ايجابية لميكروب الكلوستريديم بيرفرنجينز من أصل 56 عينه من الأسماك المصنعة بنسبة 57.1٪ وتم عزل 34 عينه ايجابية من أصل 57 عينة من الأسماك الغير المصنعة بنسبة 59.6٪. تم تطبيق تفاعل الناجلرز على العترات المعزولة لمعرفة تأثير إنزيم الليسيسينيز لسم الألفا على الليسيسين لصفار البيض. فى هذه الدراسة نم تصنيف جميع العترات المعزولة فكانت العترات المسمة بنسبة 84.8٪ والعترات الغير مسممة بنسبة 15.2٪ ولوحظ أن النوع (أ) فى العترات المسمة أكثر تواجداً من النوع (د). تم إجراء اختبار الانتشار المناعي وجد ثلاثة أنواع أظهرت الايجابية والتطابق فى 17 عينة للنوع (أ) بنسبة 47.2٪ بينما النوع (د) أظهرت الايجابية والتطابق فى 11 عينة بنسبة 55٪. 